\title{
Application of organic acids in poultry nutrition
}

\begin{abstract}
It is well known that the risk of bacteria acquiring resistance to specific antibiotics and antibiotic residues in meat led to a ban of antibiotics as growth promoters in European Union (EU) since January 2006. Organic acids have gained significant attention due to their high nutritional value and antimicrobial benefits. Major countries of production scene for feed acidifiers include the United States, China, Brazil, Mexico, and Japan, and demand is on the rise in developing regions such as Latin America, Asia-Pacific, and the Middle East. Thus, the purpose of this paper is to review the potential of using organic acids in poultry nutrition.
\end{abstract}

Volume 3 Issue 4 - 2018

\author{
Hosna Hajati \\ Payame Noor University of Sari, Iran
}

Correspondence: Hosna Hajati, Payame Noor University of Sari, Sari, Iran, Email H.Hajati@ut.ac.ir

Received: February 20, 2018| Published: August 24, 2018

Keywords: Organic acids, broiler, layer, breeder

\section{Introduction}

Nowadays, there is an increased public awareness about the risk of developing cross-resistance of pathogens to antibiotics. ${ }^{1}$ Organic acids, such as propionic acid, have been used for more than 30 years to reduce bacterial growth and mould in feedstuffs and thus preserve hygienic quality. Health and performance promoting effects have been demonstrated for a number of organic acids, including formic, fumaric, citric and lactic acid and their salts. In animal rearing, higher feed conversion rates and daily gain as well as reduced incidence of diarrhea, enhance economic return by lower feed costs and shorter time to market may achieved by organic acid supplementation. ${ }^{2}$

\section{Organic acid definition}

The term "organic acid" refers to a broad class of compounds used in fundamental metabolic processes of the body. Chemically, organic acids share the common features of water solubility, acidity, and ninhydrin-negativity (no primary or secondary amines). The term is generally considered to include all carboxylic acids, with or without keto, hydroxyl, or other non-amino functional groups, but does not include most amino acids. Some nitrogen-containing compounds are included, such as pyroglutamate, or amino conjugates like hippurate (benzoylglycine). Short chain fatty acids are also contained in this group (Figure 1).
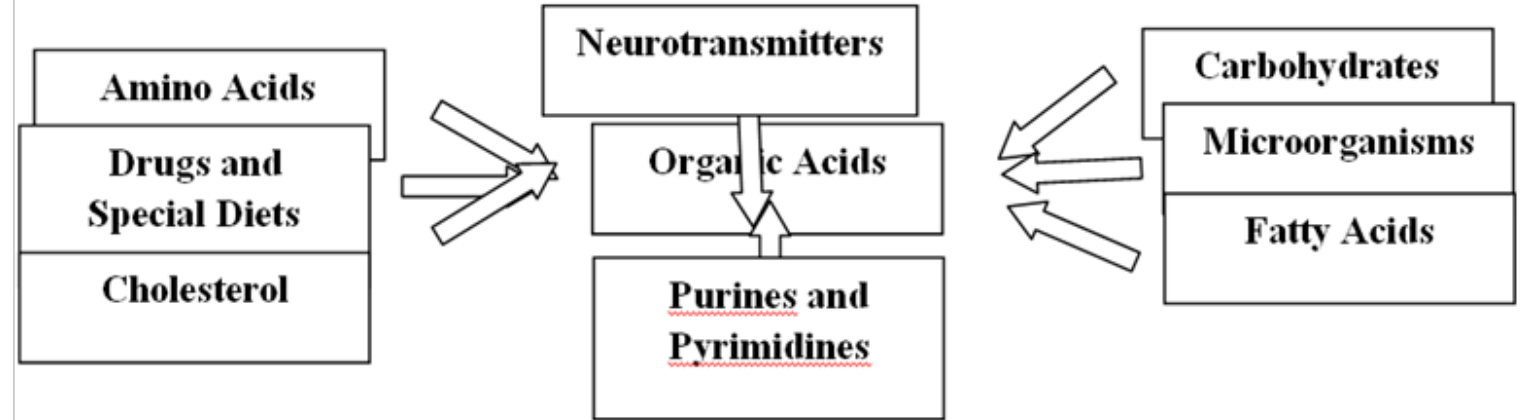

Figure I Pathways of organic acid production.

They are either" Simple monocarboxylic acids such as formic, acetic, propionic and butyric acids or " Carboxylic acids with hydroxyl group such as lactic, malic, tartaric and citric acids or "Short chain carboxylic acids containing double bonds like fumaric and sorbic acids. ${ }^{3}$ As a group of chemicals, organic acids are considered to be any organic carboxylic acid of the general structure R-COOH (including fatty acids and amino acids). Not all of these acids have effects on gut microflora. Organic acids with specific antimicrobial activity are short-chain acids $(\mathrm{C} 1-\mathrm{C} 7)$ and they are widely distributed in nature as normal constituents of plants or animal tissues. ${ }^{4}$ They are also formed through microbial fermentation of carbohydrates mainly in the large intestine. They are sometimes found as their sodium, potassium or calcium salts. Most organic acids with antimicrobial activity have a $\mathrm{pKa}-$ (the $\mathrm{pH}$ at which the acid is half dissociated)-between 3 and 5 . Table 1 shows the common name, chemical name, formula and first pKa of organic acids that are commonly used as dietary acidifiers in monogastric animals.
Table I List of organic acids and their properties used as dietary acidifiers in poultry and pigs ${ }^{4}$

\begin{tabular}{ll} 
Organic acid & MEn $(\mathbf{M J} / \mathbf{K g})$ \\
\hline Formic & 11.34 \\
Acetic & 12.19 \\
Propionic & 17.78 \\
Butyric & 22.43 \\
Lactic & 14.53 \\
Malic & 9.79 \\
Citric & 10.29
\end{tabular}

\section{Considerations before selecting organic acid for poultry nutrition}

Before any diet manipulation, we should consider the gastrointestinal characteristics and microbial ecosystems of poultry. Figure 
2 show the $\mathrm{pH}$, resident time of feed and microbial population in gastrointestinal tract of chicken. Organic acids and their salts exert growth inhibiting effects on stomach and gut microbes through $\mathrm{pH}$ reduction and anion and proton effects in the microbial cell. Growth rates of many microbes like Cl. Perfringens, E. coli or Salmonella ssp. are reduced below $\mathrm{pH} 5$, while acid tolerant microbes are unharmed. Optimum pH for Escherichia coli, Lactobacillus spp., Salmonella spp. Camplylobacter jejuni growth are 6-8, 5.4-6.4, 6.8-7.2, and 6.8-7.2, respectively. Acids used as feed additives have $\mathrm{pK}$ values between 3 and 5 , and are categorized as being of intermediate strength. ${ }^{2}$

\begin{tabular}{|c|c|c|c|c|c|}
\hline $\begin{array}{l}\text { Microflora } \\
3 \text { weeks }\end{array}$ & Parts & $\begin{array}{l}\text { Gastro- } \\
\text { intestinaltract }\end{array}$ & $\mathrm{pH}$ & $\begin{array}{l}\text { Resident } \\
\text { time } \\
\text { Minutes }\end{array}$ & $\begin{array}{l}\text { Microflora } \\
\text { Adult }\end{array}$ \\
\hline $\begin{array}{l}\text { Streptococci' } \\
\text { Coliform' } \\
\text { Lactobacilli' }\end{array}$ & Crop & & $4.5-5.3$ & 45 & $\begin{array}{l}\text { Streptococci }{ }^{2} \\
\text { Coliform } \\
\text { Lactobacillij }^{3}\end{array}$ \\
\hline $\begin{array}{l}\text { Streptococci' } \\
\text { Coliform' } \\
\text { Lactobacilli' }\end{array}$ & $\begin{array}{l}\text { Proventriculus } \\
\text { Gizzard }\end{array}$ & & $2.0-4.5$ & 70 & $\begin{array}{l}\text { Streptococci } \\
\text { Coliform } \\
\text { Lactobacilli }^{3}\end{array}$ \\
\hline $\begin{array}{l}\text { Streptococci' } \\
\text { Coliform ' } \\
\text { Lactobacilli' }\end{array}$ & Ileum & & $5.6-7.9$ & $160-200$ & $\begin{array}{l}\text { Streptococci' } \\
\text { Coliform' } \\
\text { Lactobacilli' }\end{array}$ \\
\hline $\begin{array}{l}\text { Streptococci' } \\
\text { Coliform } 1 \\
\text { Lactobacilli3 }\end{array}$ & Caeca & & $5.8-6.8$ & 120 & $\begin{array}{l}\text { Bacteroidesi' } \\
\text { Bifidobacteria' } \\
\text { Peptostreptococci' } \\
\text { Clostridia' } \\
\text { Propionic bacteria' } \\
\text { Eubacteria' }\end{array}$ \\
\hline $\begin{array}{l}\text { Streptococci' } \\
\text { Coliform' } \\
\text { Lactobacilli }\end{array}$ & $\begin{array}{l}\text { Colon } \\
\text { Rectum }\end{array}$ & & $6.3-7.7$ & $30-50$ & $\begin{array}{l}\text { Mixture: } \\
\text { lleal and caecal bacteria }\end{array}$ \\
\hline
\end{tabular}

Figure $2 \mathrm{pH}$, resident time of feed and microbial population in gastrointestinal tract of chicken.

'Dominant; ${ }^{2}$ Predominant; ${ }^{3}$ Significant.

Acidifiers are used in three ways in a poultry operation:

i. Added to the poultry feed in a solid form. This fights mold development in the feed and reduces the $\mathrm{pH}$ in the birds' crops.

ii. Sprayed onto the poultry litter. This attacks the bacteria that facilitate the breakdown of uric acid, limiting the amount of ammonia releases.

Injected into the water to kill bacteria, facilitate chlorine in killing bacteria and lowering the $\mathrm{pH}$ in the birds' crops. The effect on gramnegative bacteria is increased if the organic acid is not dissociated (Figure 3). Because of this mode of action acidifier need to contain organic acids which are undissociated at different $\mathrm{pH}$-values, so that the anti microbial action is prolonged over a wider $\mathrm{pH}$ range. ${ }^{5,6}$

As the energy content of organic acids is made completely available during metabolism, it should be considered in the energy calculation of feed rations (Figure 4). For example, propionic acid contains up to five times more energy than wheat. ${ }^{7}$ The effects of organic acids in the reduction of $\mathrm{pH}$ and their antimicrobial activity vary considerably depending on their dissociation status. The amount of dissociation depends on the $\mathrm{pH}$ value of the environment, which is described by the specific $\mathrm{pK}$ (dissociation constant) value for each acid. The lower the $\mathrm{pK}$ value, the stronger the acid, which relates to its ability to lower the $\mathrm{pH}$ of the environment.

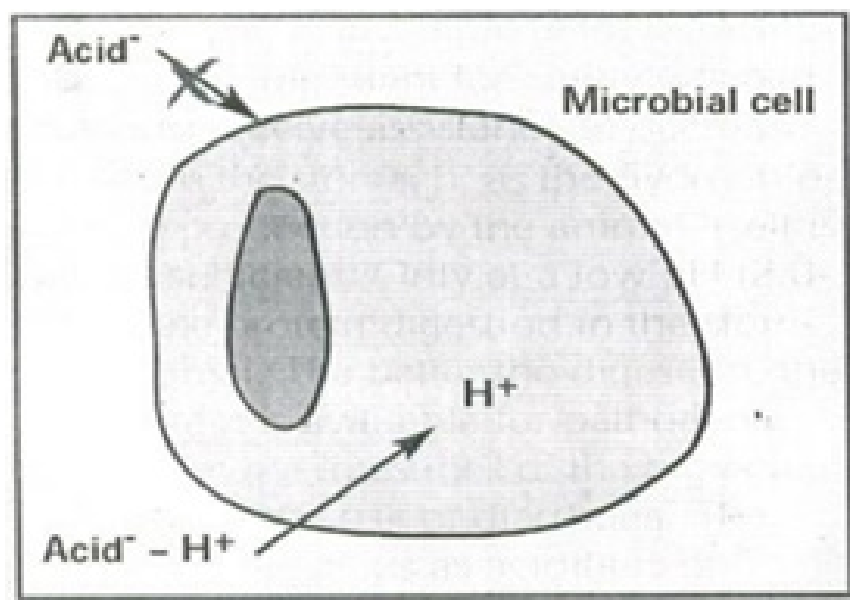

Figure 3 Not dissociated acid penetrates the microbial cell membrane.

Factors influencing the efficiency of dietary organic acid supplementation

- pKa-value

- $\quad$ Chemical form (acid, salt, coated or not) 
- Molecular weight

- $\quad$ MIC-value of the acid

- Kind of micro-organism
- Animal species,

- Site and location in the gastro-intestinal tract

- Buffering capacity of the feed

\begin{tabular}{llll}
\hline Acid & Chemical name & Formula & pKa \\
\hline Formic & Formic acid & $\mathrm{HCOOH}$ & 3.75 \\
Acetic & Acetic acid & $\mathrm{CH}_{3} \mathrm{COOH}$ & 4.76 \\
Propionic & 2-Propanoic acid & $\mathrm{CH}_{3} \mathrm{CH}_{2} \mathrm{COOH}$ & 4.88 \\
Butyric & Butanoic acid & $\mathrm{CH}_{3} \mathrm{CH}_{2} \mathrm{CH}_{2} \mathrm{COOH}$ & 4.82 \\
Lactic & 2-Hydroxypropanoic acid & $\mathrm{CH}_{3} \mathrm{CH}(\mathrm{OH}) \mathrm{COOH}$ & 3.83 \\
Sorbic & 2,4-Hexandienoic acid & $\mathrm{CH}_{3} \mathrm{CH}: \mathrm{CHCH}: \mathrm{CHCOOH}$ & 4.76 \\
Fumaric & 2-Butenedioic acid & $\mathrm{COOHCH}: \mathrm{CHCOOH}$ & 3.02 \\
Malic & Hydroxybutanedioic acid & $\mathrm{COOHCH}$ & \\
Tartaric & 2,3-Dihydroxy- Butanedioic acid & $\mathrm{COOHCH}(\mathrm{OH}) \mathrm{CH}(\mathrm{OH}) \mathrm{COOH}$ & 3.40 \\
Citric & 2-Hydroxy-1,2,3- Propanetricarboxylic acid & $\mathrm{COOHCH}$ & $\mathrm{C}(\mathrm{OH})(\mathrm{COOH}) \mathrm{CH} \mathrm{COOH}_{2}$ \\
Benzoic & Benzenecarboxylic acid & $\mathrm{C}_{6} \mathrm{H}_{5} \mathrm{COOH}$ & 2.93 \\
\hline
\end{tabular}

Figure 4 Men content of common organic acids in poultry feed. 3

\section{Buffering capacity of dietary ingredients}

Buffering capacity is a measure of the amount of acid $(0.1 \mathrm{M}$ $\mathrm{HCL}$ ) required to reach a given $\mathrm{pH}$ (usually 3 to 5) of a 10-g slurried sample of the ingredient. ${ }^{8}$ The ingredients that contribute most to the buffering capacity are proteins and minerals. Cereals and cereal byproducts tend to have a low buffering capacity. Organic acids reduce the buffering capacity of the diet, which is critical to effective enzyme activity and control of microbial proliferation. Blank et al., ${ }^{9}$ observed that increasing the buffering capacity from 23.5 to 56.7 decreased the ileal amino acid digestibilities up to $10 \%$. A recommended buffering capacity value for poultry starter diets is 0 to $10 .{ }^{8}$ Acid- binding capacity, $\mathrm{pH}$ and $\mathrm{B}$-value of some ingredients are shown in Table 2 and Table 3 , respectively.

Table 2 Acid-binding Capacity of feed ingredients at $\mathrm{pH} 3$

\begin{tabular}{ll}
\hline Raw Material & meq/kg (Min./Max) \\
\hline Wheat & $180 / 240$ \\
Corn & $135 / 172$ \\
Soybean meal 42 & $980 / 1240$ \\
Soybean meal 48 & $1025 / 1035$ \\
Fish meal & $1480 / 2100$ \\
Calcium Carbonate & $19680 / 20000$ \\
Dicalcium Phosphate & $7860 / 10150$ \\
\hline
\end{tabular}

\section{Feed Acidification Strategies}

Form of Organic acids incorporated:

i. Free acid form (powder, liquid).

ii. As salts form: a) Free form, b) Protected/Coated salts.

\section{Common inclusion levels of organic acids in poultry feed:}

i. At $0.5 \mathrm{~kg} /$ Ton of feed to control molds

ii. At 2.5 to $3.0 \mathrm{~kg} /$ Ton of feed to reduce $\mathrm{pH}$ and help in control of Salmonella.
Table $3 \mathrm{pH}$ and $\mathrm{B}$-value of some common feed ingredients

\begin{tabular}{lll}
\hline Feed Ingredient & pH & B value \\
\hline Rice & 6.5 & 2.8 \\
Barely & 5.8 & 3 \\
Maize & 6.1 & 3.5 \\
Wheat & 6.7 & 3.7 \\
Sorghum & 5.9 & 5 \\
Triticale & 6.8 & 7 \\
Soybeans & 6.3 & 18 \\
Sunflower & 6.1 & 16.4 \\
Meat and bone meal & 8.3 & 32 \\
Dicalcium phosphate & 7.3 & 248 \\
Limestone & 9.7 & 1750
\end{tabular}

\section{Mode of action of organic acids}

Like antibiotics, organic acids have an antimicrobial activity. The acids can penetrate the bacterial cell wall and disrupt the normal actions of certain types of bacteria including Salmonella spp, E. coli, Clostridia spp, Listeria spp. and some coliforms. Therefore, reduction in numbers of some species of the normal intestinal bacteria as well as pathogenic bacteria can occur in animals fed organic acids. ${ }^{6}$

\section{Antibacterial spectrum of organic acids}

Each acid has its own spectrum of antimicrobial activity. For example, sorbic acid is better known for its antimold activity, but lactic acid is more effective against bacteria. Formic acid, propionic acid and HMB have broader antimicrobial activities and can be effective against bacteria and fungi, including yeast. ${ }^{10,11}$ It has been reported that blends of some acids have synergistic antimicrobial activity in vitro. ${ }^{12}$ The MIC for acetic, butyric, lactic and caprylic acid in $E$. coli are less than $4 \mathrm{~g} / 1$, but this same bacterium is approximately 10-times more resistant to malic, tartaric and citric acid (Hsiao and Siebert, 2002). 


\section{Using Organic Acid in poultry nutrition}

One of the first reports of improved broiler performance was for formic acid, when diets were supplemented with single acids. ${ }^{13}$ Subsequently, Izat et al., ${ }^{14}$ reported reduced levels of Salmonella spp. in carcass and caecal samples after including calcium formate in broiler diets. Izat et al., ${ }^{15}$ showed that buffered propionic acid could be used to counteract pathogenic microfelora in the intestine of broiler chickens, which resulted in a significant reduction in carcass contamination with Escherichia coli and Salmonella spp. The use of pure formic acid in breeder diets reduced the contamination of tray liners and hatchery waste with S. enteritidis. ${ }^{16}$ Organic acids have strong bacteriostatic effects and have been used as Salmonella-control agents in feed and water supplies for poultry. ${ }^{17}$ Acidification with various weak organic acids to diets such as formic, fumaric, propionic, lactic and sorbic acid have been reported to decrease colonization of pathogen and production of toxic metabolites, improve digestibility of protein and of $\mathrm{Ca}, \mathrm{P}$, $\mathrm{Mg}$ and $\mathrm{Zn}$ and serve as substrates in the intermediary metabolism.
Several studies demonstrated that supplementation of organic acids to broiler diets increased growth performance, reduced diseases and management problems. ${ }^{18-20}$ Hinton \& Linton ${ }^{21}$ studied salmonella infections in broilers using a mixture of formic and propionic acids. They demonstrated that $6 \mathrm{~kg} / \mathrm{t}(0.6 \%)$ of this organic acid blend was effective in preventing intestinal colonization with Salmonella spp. from naturally or artificially contaminated feed. Improvements in broiler performance and hygiene in response to organic acids are often reported. However, an important limitation is that organic acids are rapidly metabolized in the foregut (the crop to the gizzard), which will reduce their impact on growth performance. Double salts of organic acids, such as potassium diformate and sodium diformate, which reach the small intestine, have been shown to have a significant impact. Selle et al., ${ }^{22}$ demonstrated the effects of potassium diformate at dosages of $0.3-1.2 \%$ until 35 days post-hatch on nutrient utilisation (Figure 5). Furthermore, diformates reduced numbers of pathogenic bacteria (Salmonella, Campylobacter and Enterobacter) in broiler chickens and increased numbers of Lactobacilli and Bifidobacteria.

\begin{tabular}{lcccc}
\hline & Control & $0.3 \% \mathrm{KDF}$ & $0.6 \% \mathrm{KDF}$ & $1.2 \% \mathrm{KDF}$ \\
\hline l-35 days post hatch & & & & \\
Weight gain $(\mathrm{g})$ & 1785 & 1808 & 1889 & 1853 \\
Feed intake $(\mathrm{g})$ & $2836^{\mathrm{a}}$ & $2800^{\mathrm{a}}$ & $3083^{\mathrm{b}}$ & $2898^{\mathrm{a}}$ \\
Feed conversion ratio & 1.59 & 1.55 & 1.63 & 1.57 \\
l6-35 days post hatch & & & $1556^{\mathrm{b}}$ & $1528^{\mathrm{ab}}$ \\
Weight gain $(\mathrm{g})$ & $1478^{\mathrm{a}}$ & $1488^{\mathrm{a}}$ & $2652^{\mathrm{b}}$ & $2480^{\mathrm{a}}$ \\
Feed intake $(\mathrm{g})$ & $2426^{\mathrm{a}}$ & $2380^{\mathrm{a}}$ & 1.70 & 1.62 \\
Feed conversion ratio & 1.64 & 1.60 & & $14.21^{\mathrm{b}}$ \\
& & & $13.98^{\mathrm{ab}}$ & $56.8^{\mathrm{b}}$ \\
AME $(\mathrm{MJ} / \mathrm{kg}$ DM) & $13.73^{\mathrm{a}}$ & $14.33^{\mathrm{b}}$ & $53.8^{\mathrm{a}}$ & \\
N retention $(\%)$ & $53.8^{\mathrm{a}}$ & $55.1^{\mathrm{ab}}$ &
\end{tabular}

Figure 5 Effects of potassium diformate (KDF) on growth performance, apparent metabolizable energy (AME) and N-retention of broilers from hatch until 35 days post-hatch. ${ }^{18}$

Mikkelsen et al., ${ }^{23}$ showed that $0.45 \%$ potassium diformate reduced mortality caused by necrotic enteritis (Clostridium perfringens). After the necrotic enteritis outbreak (day 35 of the trial period), KDF significantly reduced the number of $C$. perfringens in the jejunum, in agreement with results showing that formic acid inhibits growth of $C$. perfringens ${ }^{24}$ in vitro. It is possible to decrease chicken carcass and egg contaminations by adding organic acids to the feed or drinking water at appropriate times. Medium-chain fatty acids have more antibacterial effect against Salmonella than short-chain fatty acids. The antibacterial effect of these acids is species-specific. Bacteria that are unable to decrease intracellular $\mathrm{pH}$ accumulate organic acid anions in accordance with the $\mathrm{pH}$ gradient across their cell membranes. The short-chain fatty acid butyrate specifically down-regulates expression of invasion genes in Salmonella spp. at low doses. Also medium-chain fatty acids and propionate decrease the ability of Salmonella spp. to invade epithelial cells, in contrast to acetic acid. ${ }^{25}$

Several studies support the statement that the addition of citric acid to broiler rations improved weight gain, ${ }^{26,27}$ increased feed consumption, ${ }^{28}$ and improved feed efficiency. ${ }^{29}$ Its addition, its use increased retention of phosphorus, ${ }^{30,31}$ tibia ash, ${ }^{32,33}$ and toe ash ${ }^{34}$ in broiler chicks. It also decreased $\mathrm{pH}$ of cecal digesta, crop and gizzard, ${ }^{35}$ and intestine ${ }^{36}$ in broiler chicks and improved immune responses by

\section{broilers..$^{29,37}$}

An experiment was carried out by Yesilbag \& Colpan $^{38}$ determine the effects of dietary organic acid supplementation $(0.5,1.0$, and 1.5 $\%$ ) on performance (bodyive weight, feed intake, feed efficiency, and egg production), egg quality and blood parameters in laying hens. The hens were fed with diets $(17 \%$ crude protein and $2800 \mathrm{kcal} / \mathrm{kg}$ metabolic energy) supplemented with $0 \%$ (control group), $0.5 \%$, $1.0 \%$, or $1.5 \%$ organic acid mixture (formic and propionic acids, and their ammonium salts) during 18 weeks. The dietary organic acid supplementation did not significantly affect growth performance (body weight, food consumption) and egg quality parameters, but markedly improved the egg production, by accelerating the laying capacity and prolonging the laying period in 24-28 week old and 3638 week old hens respectively and the feed efficiency at a lesser extent. Serum total protein $(\mathrm{p}<0.01)$ and albumin concentrations $(\mathrm{p}<0.05)$ as well as AST activity $(p<0.05)$ were significantly increased, whereas the other tested serum parameters (ALT activity and cholesterol, HDL, triglyceride, VLDL and total lipid concentrations) were unaffected. They concluded that dietary supplementation with organic acids and their salts could be used in layer hens with benefit on egg production and protein metabolism efficiency. Some previous results of using organic acid in broilers are listed in Figure $6 .{ }^{3}$ 


\begin{tabular}{|c|c|c|}
\hline Acid & Concentration (\%) & Effects \\
\hline Fumaric acid & $0.50-1.00$ & $\begin{array}{l}\text { Improvement in weight gain of broilers. } \\
\text { Improved feed efficiency in both broilers and layers. }\end{array}$ \\
\hline $\begin{array}{l}\text { Buffered } \\
\text { propionic acid }\end{array}$ & $0.15-0.20$ & $\begin{array}{l}\text { Increase in dressing percentage in female broilers } \\
\text { and reduction in abdominal fat for males. }\end{array}$ \\
\hline Malic acid & $0.50-2.00$ & Increase in weight gain \\
\hline Sorbic acid & 1.12 & Improves feed efficiency \\
\hline Tartaric acid & 0.33 & Increase in weight gain \\
\hline Lactic acid & 2.00 & Feed to gain ratio significantly improved. Body weight gain. \\
\hline Formic acid & $0.50-1.00$ & Reduction of caecal pH and bactericidal effect on Salmonella \\
\hline Benzoic acid & 0.20 & Positive influence on growth \\
\hline Butyric acid & 0.15 & $\begin{array}{l}\text { Maintain the beneficial micro flora. Increase the } \\
\text { proliferation and maturation of intestinal cells }\end{array}$ \\
\hline
\end{tabular}

Figure 6 The concentration and effects of supplementing organic acid in poultry nutrition.

Acidifying drinking water of poultry for the first $7 \mathrm{~d}$ of life, when the birds are first placed into the house, is considered critical, because the crop and intestinal microbial morphology would still be under development. Maintenance of low crop $\mathrm{pH}$ by the lactic acid bacteria (LAB) in newly hatched chicks and poults is critical. The acidified drinking water provides a second layer of protection to the LAB and helps to establish them as a part of the crop's normal ecology. Once the crop's LAB population has been established, the bird will be able to maintain a low crop $\mathrm{pH}$ on its own as long as feed is available..$^{39,40}$

\section{Limitations of using organic acids in poultry nutrition}

i. Palatability may be decreased, leading to feed refusal.

ii. Organic acids are corrosive to metallic poultry equipment.

iii. Bacteria are known to develop acid resistance when exposed to acidic environments for over long term.

iv. Presence of other antimicrobial compounds can reduce its efficiency.

v. Cleanliness of the production environment.

vi. Buffering capacity of dietary ingredients.

\section{Conclusion}

Organic acids are nutrients with acidifying effects that can be used in poultry feed to prevent or combat with harmful microbial populations, so they can improve bird's health and performance in an organic manner. However, nutritionist should consider some important issues such as the type and age of birds, their gastro-intestinal tract microbial ecology, $\mathrm{pH}$ and buffering capacity of nutritional ingredients. It seems that further study is needed to recognize the exact effect of organic acids in different stages of poultries life and also in different stages of poultry's infectious diseases to determine the optimum level of each organic acid supplementation.

\section{Acknowledgements}

None.

\section{Conflicts of interest}

Author declares that there is none of the conflicts.

\section{References}

1. Hunter PA, Dawson S, French GL, et al. Antimicrobial-resistant pathogens in animals and man: prescribing, practices and policies. J Antimicrob Chemother. 2010;65(Suppl 1):3-17.

2. Freitag M. Organic acids and salts promote performance and health in animal husbandry. In: Acidifiers in animal nutrition, A guide for feed preservation and acidification to promote animal performance. Nottingham University Press; 2007. p. 89.

3. Ramasubba Reddy V. The Role of Acidifers in Poultry Nutrition. Avitech technical bulletin. 2004.

4. Papatsiros VG, Christodoulopoulos G, Filippopoulos LC. The use of organic acids in monogastric animals (swine and rabbits). Journal of Cell and Animal Biology. 2012;6(10):154-159.

5. Christian Lückstädt, Nizamettin Şenköylü, Hasan Akyürek, et al. Acidifier-A modern alternative for anti-biotic free feeding in livestock production, with special production, with special focus on broiler production. Veterinarija ir zootechnika T. 2004;27(49):1-3.

6. Suryanarayana MVAN, Suresh J, Rajasekhar MV. Organic acids in swine feeding-A Review. Agricultural Science Research Journals. 2006;2:523-533.

7. Diebold G, Eidelsburger U. Acidification of diets as an alternative to antibiotic growth promoters. In: Antimicrobial growth promoters. In: Barug D, J de Jong, Kies AK, editors. The Netherlands: Wageningen Academic Publishers; 2006. p. 311-327.

8. Makkink C. Acid binding capacity in feedstuffs. Feed International. 2001;22:24-27.

9. Blank R, Mosenthin R, Sauer WC, et al. Effect of fumaric acid and dietary buffering capacity on ileal and fecal amino acid digestibilities in earlyweaned pigs. Journal of animal science. 1999;77:2974-2984.

10. Doerr JA, Attard FA, Doerr EA, et al. Possible anti-fungal effects of hydroxy-methylthio-butanoic acid (HMB). Poultry Science. 1995;47(Suppl 1):23.

11. Partanen $\mathrm{KH}, \mathrm{Mroz} Z$. Organic acids for performance enhancement in pig diets. Nutrition Research Reviews. 1999;12(1):117-145.

12. Huyghebaert $\mathrm{G}$. The influence of the addition of organic acid preparations on the zootechnical performances of broiler chickens. Report: CLO-DVV. Institute for Animal Science and Health. Netherlands; 1999. 
13. Vogt H, Matthes S, Harnisch S. Der Einfluß organischer Säuren auf die Leistungen von Broilern und Legehennen. Archiv fur Geflugelkunde. 1981;45(5):221-232.

14. Izat AL, Adams MH, Cabel MC, et al. Effect of formic acid or calcium formate in feed on performance and microbiological characteristics of broilers. Poultry Science. 1990;69(11):1876-1882.

15. Izat AL, Tidwell NM, Thomas RA, et al. Effects of a buffered propionic acid in diets on the performance of broiler chickens and on the microflora of the intestine and carcass. Poultry Science. 1990;69(5):818-826.

16. Humphrey TJ, Lanning DG. The vertical transmission of salmonellas and formic acid treatment of chicken feed. A possible strategy for control. Epidemiology and infection. 1988;100(1):43-49.

17. Ricke SC. Perspectives on the use of organic acids and short chain fatty acids as antimicrobials. Poult Sci. 2003;82(4):632-639.

18. Gunal M, Yayli G, Kaya O, et al. The effects of antibiotic growth promoter, probiotic or organic acid supplementation on performance, intestinal microflora and tissue of broilers. Int J Poult Sci. 2006;5(2):149-155.

19. Islam KMS, Schuhmacher A, Aupperle H, et al. Fumaric acid in broiler nutrition: a dose titration study and safety aspects. Int J Poult Sci. 2008;7(9):903-907.

20. Lückstädt C, Theobald P. Effect of a formic acid-sodium formate premixture on Salmonella, Campylobacter and further gut microbiota in broilers. Proceedings and Abstracts of the $17^{\text {th }}$ European Symposium on Poultry Nutrition. 2009. p. 246.

21. Hinton M, Linton AH. Control of Salmonella infections in broiler chickens by the acid treatment of their feed. Veterinary record. 1988;123(16):416-421.

22. Selle PH, Huang KH, Muir WI. Effects of potassium diformate inclusion in broiler diets on growth performance and nutrient utilisation. Proceedings of the Australian Poultry Science Symposium. 2004;16:55-58.

23. Mikkelsen LL, Vidanarachchi JK, Olnood CG, et al. Effect of potassium diformate on growth performance and gut microbiota in broiler chickens challenged with necrotic enteritis. British poultry science. 2009;50(1):66-75.

24. Mroz Z. Organic acids as potential alternatives to antibiotic growth promoters for pigs. Advances in pork production. 2005;16:169-182.

25. Van Immerseel, Russell JB, Flythe MD, et al. The use of organic acids to combat Salmonella in poultry: a mechanistic explanation of the efficacy. Avian pathology. 2006;35(3):182-188.

26. Afsharmanesh M, Pourreza J. Effect of calcium, citric acid, ascorbic acid, vitamin $\mathrm{D}_{3}$ on the efficacy of microbial phytase in broiler starters fed wheatbased diets on performance, bone mineralization and ileal digestibility. International Journal of Poultry Science. 2005;4(6):418-424.

27. Nezhad YE, Shivazad M, Nazeeradl M, et al. Influence of citric acid and microbial phytase on performance and phytate utilization in broiler chicks fed a corn-soybean meal diet. Journal Faculty Veterinary Medicine University of Tehran. 2007;61(4):407-413.
28. Moghadam AN, Pourreza J, Samie AH. Effect of different levels of citric acid on calcium and phosphorus efficiencies in broiler chicks. Pakistan Journal of Biological Sciences. 2006;94(9):1250-1256.

29. Abdel-Fattah SA, Ei-Sanhoury MH, Ei-Mednay NM, et al. Thyroid activity of broiler chicks fed supplemental organic acids. International Journal of Poultry Science. 2008;7:215-222.

30. Brenes A, Viveros A, Arija I, et al. The effect of citric acid and microbial phytase on mineral utilization in broiler chicks. Animal Feed Science and Technology. 2007;48(4):469-479.

31. Liem A, Pesti GM, Edwards HM. The effect of several organic acids on phytase phosphorus hydrolysis in broiler chicks. Poultry Science. 2008;87(4):689-693.

32. Rafacz-Livingston KA, Parsons CM, Jungk RA. The effects of various organic acids on phytate phosphorus utilization in chicks. Poultry Science. 2005;84(9):1356-1362.

33. Martinez-Amezcua C, Parsons CM, Baker DH. Effect of microbial phytase and citric acid on phosphorus bioavailability, apparent metabolizable energy, and amino acid digestibility in distillers dried grains with soluble in chicks. Poultry Science. 2006;85(3):470-475.

34. Atapattu NSBM, Nelligaswatta CJ. Effects of citric acid on the performance and utilization of phosphorous and crude protein in broiler chickens fed rice byproducts based diets. International Journal of Poultry Science. 2005;4(12):990-993.

35. Andrys R, Klecker D, Zeman L, et al. The effect of changed $\mathrm{pH}$ values of feed in isophosphoric diets on chicken broiler performance. Czech Journal of Animal Science. 2003;48(5):197-206.

36. Denil M, Okan F, Celik K. Effect of dietary probiotic, organic acid and antibiotic supplementation to diets on broiler performance and carcass yield. Pakistan Journal of Nutrition. 2003;2(2):89-91.

37. Rahmani HR, Speer W. Natural additives influence the performance and humoral immunity of broilers. International Journal of Poultry Science. 2005;4(9):713-717.

38. Yesilbag D, Colpan I. Effects of Organic Acid Supplemented Diets on Growth Performance, Egg Production and Quality and on Serum Parameters in Laying Hens. Revue Méd Vét. 2006;157(5):280-284.

39. Menconi A, Kuttappan VA, Hernandez-Velasco X, et al. Evaluation of a commercially available organic acid product on body weight loss, carcass yield, and meat quality during preslaughter feed withdrawal in broiler chickens: A poultry welfare and economic perspective. Poultry Science. 2014;93(2):448-455.

40. Dawson A. Effect of enzyme supplementation and acidification of diets on nutrient digestibility and growth performance of broiler chicks. Poult Sci. 2009;88(1):111-117. 